\title{
Application of technology in the digital era education
}

\author{
Harwati Hashim \\ Universiti Kebangsaan Malaysia, Selangor Malaysia \\ *Corresponding author, e-mail: harwati@ukm.edu.my
}

\begin{abstract}
The fact that technology plays a much larger role in the digital era than it did for previous generations has made today's generation having a high level of technological literacy. The increase in this literacy coupled with recent technological advances has led to the expansion of technology in education. From the millennial to Gen-Z, these are the generations that are coming into the classroom today and they share unique characteristics that define their generations. These generations expect to be engaged in their learning and they do not do well being passive learners. Hence, technology has to be embraced in today's education and teachers have to apply technology as part of the students learning. This paper reviews the generations of learners that teachers are having today and how these generations impacted the transformation of education in the digital era. This paper also presents some of the emerging technologies and discusses the needs of pedagogical transformation to invent new forms of teaching and learning as well as the importance of redesigning and rethinking education in the digital era.
\end{abstract}

Keywords: technology in education; education in the digital era; millennial generations; Gen-Z; SAMR Model; technology for teaching and learning.

How to Cite: Hashim, H. (2018). Application of technology in the digital era education. International Journal of Research in Counseling and Education, 2(1), 1-5. https://doi.org/10.24036/002za0002

This is an open access article distributed under the Creative Commons 4.0 Attribution License, which permits unrestricted use, distribution, and reproduction in any medium, provided the original work is properly cited. (๑2018 by Author.

\section{Introduction}

Without a doubt, technology will be a crucial part of the education in the digital era. Emerging technology such as cloud computing, Augmented Reality (AR) and 3D printing are paving the way for the future of education. Moreover, in this digital era, it is all about access, anywhere learning and collaboration, both locally and globally. Undeniably, education is already starting to move their way with the emergence of current technology. With the help of technology, the process of teaching and learning is no longer restricted to the classroom. With the rapid development of technology, the emerging and developing of technology and its application to teaching comes into full play in education.

Consequently, educators are facing challenges in adapting their teaching styles to accommodate a new generation of learners. The new generation of learners, who are now entering schools, colleges and universities, have learning expectations, styles, and needs that are different from past students. Thus, this paper reviews the generations of learners that teachers are having today and how these generations impacted the transformation of education in the digital era. This paper also presents some of the emerging technologies and discusses the needs of pedagogical transformation to invent new forms of teaching and learning as well as the importance of redesigning and rethinking education in the digital era.

\section{The New Generation of Learners}

A common way to classify the generations is based on the time period in which one was born. Oblinger and Oblinger (2005) developed a classification system that describes various generations as Matures (19001946), Boomers (1946-1964), Generation X (1965-1982), and Gen-Y/Millennials (1983-1991). This classification demonstrates the often noted overlap in years among classifications. Howe and Strauss (2000) classified the generations as: Boomers (1943-1960), Gen-X (1961-1981) and Millennials (1982-1994). However, the student population crosses all generations with the newest, the Gen-Z or Net Generation, being distinctly different in their characteristics and learning expectations. In the age of the digital era, the two generations that impacted education the most are the Gen Y/Millennials and Gen-Z/Net Generation. 
Students born between 1982 and 2000 are categorised the millennial generation or also known as Gen-Y and are often described as being digital natives who have a high level of technological literacy (Best et al. 2013). The increase in student literacy coupled with recent technological advances has led to the expansion of technology in education. Howe and Strauss (2000) popularised the term Millennial and proposed that these students share unique characteristics that define their generation. Millennials expect to be engaged in their learning and they do not do well being passive learners. Hence, teachers must have technologies that will be part of the students learning. These technologies include the smart phones, laptop, computers and the internet. Howe and Strauss (2003) suggested that the millennial generation is characterised by seven common traits and can be perceived as achievement-oriented, team-oriented, pressured, conventional, confident, sheltered, and special.

Compared to the millennials, Generation Z (Gen-Z) are those who were born roughly between 1995 and 2010 (Rothman, 2014). Generation $Z$ is unique as they were born during the introduction of the graphical web that resembles the Internet today and they have also experienced the rise of mobile devices, and cloud computing. This generation is tech-savvy and prefers to communicate using social media over direct contact with people. They are the first generation born into an integrated and globally connected world where the Internet has always been available. Due to their unique characteristics, Gen-Z has a different need to engage in learning. Gen-Z needs fast delivery of content with complex graphics. They are kinaesthetic, experiential, hands-on learners who prefer to learn by doing rather than being told what to do or by reading text. They also prefer random access, graphics first and connected activities. Obviously, they have a need for speed and instant gratification.

According to Rothman (2014), task switching (multitasking) has given the Gen-Z a short attention span. Thus, learning could be difficult for them as they get bored easily and ready to move into the next thing. Due to this, learning needs have to be delivered in smaller "bites" which is known as "bite-sized learning". Gen Z will learn more effectively if they are left to solve problems and find solutions by trial and error. Their gaming experience has centred on solving problems before they can move to the next level. They will continue to work on a level of a game for a long time because they realise that each time they fail, they have just learned one more strategy and now know that it won't work. In this matter, gamified-learning suits them best which can be embedded with challenge-based learning. Gen-Z also has access to too much data which makes them go for the quick answer rather than the longer problem-solving approach. For this generation, cheating and hacking are considered brilliant. This generation prefers to work in teams/small groups. Creativity and collaboration are natural to them, whether it is a spontaneous or structured activity. They need the flexibility to learn in the way that works best for them. They need options to choose from, so learning can be personalized. This makes them more reflective and independent learners than other generations.

Above all, due to the unique characteristics of the new generation of learners, teachers could not run away from integrating and applying technology in teaching and learning. For these learners, technology is not considered an accessory to life but is viewed as a way of life. This has implications on pedagogy and it demands the transformation of education.

\section{The Emerging Technology}

As newer technology makes its way into classrooms, learners are able to learn at increasingly faster rates. The following sections discuss the emerging technology that can be applied in education in the digital era.

\section{Cloud Computing}

Cloud computing is Internet-based computing in which shared resources, software and information are delivered as a service that computers or mobile devices can access on demand (Kiran 2014). Cloud computing is already used extensively in education. Free or low-cost cloud-based services are used daily by learners and educators to support learning, social interaction, content creation, publishing and collaboration. Examples of cloud-based tools include Massive Open Online Courses (MOOC), Open Educational Resources (OER), Google Apps, YouTube, Twitter and Drop box. Today more services, tools and applications are being provided in the cloud. Cloud-based tools and applications will bring flexibility and new possibilities for improving teaching and learning.

\section{Mobile Technology}

Mobile technology has become an important tool in the teaching and learning process. Studies have shown that technologies especially the use of mobile devices does bring positive impacts in improving teaching and learning. The mobile technology involves connectivity for downloading, uploading and/or online working via wireless and/or mobile networks. The main platforms for such connectivity usually include mobile phones, smart phones, PDAs, MP3/MP4 players (e.g., iPod), tablets, wireless laptop PCs, mini notebooks or netbooks, and handheld gaming devices (Kukulska-Hulme et al., 2009). Therefore, mobile 
technology is one of the recent effective technologies to support learning in the real world. Mobile technology affords more accessibility to learning resources whenever and wherever learners are (Sharples et al., 2007). This indicated two significant advantages for learning in different contexts: flexibility of time and flexibility of locations.

\section{Massive Open Online Courses (MOOCs)}

Massive Open Online Courses (MOOCs) have entered the education environment and are already making waves. MOOC is an online platform where everyone can enrol because the courses offered are free. Massive Open Online Courses (MOOCs), has become widespread among academicians around the world. There are now multiple MOOC platforms, offering hundreds of courses. Besides, there are also some of the courses offered in MOOCs have hundreds of thousands of students enrolled. Basically, MOOCs is like a university-level courses offered online. There are many benefits that institutions could derive from offering MOOC. MOOC forum actually gives the opportunity to the enroller to develop their critical and creative thinking which they can obtain through the discussion in the forum by interacting with other participants in the forum and sharing idea. On top of that, a distinguishing feature of a MOOC is that there is no course fee imposed on learners (Balfour, 2013).

\section{Games and Gamification}

Referred to as "Game-Based Learning", this emerging technology has expanded far beyond integrating digital and online games into learning. Games are effective tools for scaffolding concepts and simulating real world experience. Games also enable learners to acquire new knowledge and enhance learning through multiple intelligences (Iaremenko, 2017). There are many online applications/games that could be utilized in teaching and learning. Among the simplest ways to engage students in gamified learning is to try web resources such as Kahoot, Quizlet, Quizziz, Socrative and many more.

\section{Augmented Reality}

Augmented reality (AR) technology has a great potential for all areas. AR allows the users to add digital content to printed material or objects. Then using a smart device or tablet, viewers can scan an object and the digital content will appear. The digital information can range from a link to a website, an invitation to make a phone call, a video, a 3D model or any other supported digital information. Augmented Reality was one of the most developed emerging technologies in 2016 (Ozdamali \& Hursen, 2017). Augmented reality has more of the real world represented than virtual reality (Hawkinson et al., 2017). An example of AR is Pokémon GO which was a trend in 2016, in which real situations were augmented with Pokemon characters for players to catch.

\section{Virtual Reality}

Virtual reality reflects the current trend in current education toward more authentic online education. The term Virtual Reality is not new but rather has broadened recently. VR uses additional tools such as VR goggles which help to present an artificial environment using sounds, 3D images, or other stimuli to give the impression of immersing in a non-physical world. In virtual reality, the role of memory in learning has proven to improve language skills (Yaseen \& Shakir, 2015). A number of studies have postulated that this new wave of gadgets can replicate the classroom learning environment (Madini \& Alshaikhi, 2017).

\section{Pedagogical Implications: Rethinking and Redesigning Education in the Digital Era}

There is no question that this new generation of learners is challenging the traditional teaching paradigm in education. In order to accommodate the new generation of learners, it is important to devise learning activities that align with their learning styles and expectations. Visualizations, simulations, case analyses, and other methods of participatory learning such as fieldwork are all part of the learning repertoire. Apart from that, the use of simulation technology will help engage learners in a process that provides the interaction they desire with the feedback they need in real-time situations. Providing adaptable approaches to learning also enables teachers to meet the needs of diverse learners.

Above all, the important key is to effectively use the technology in education. The Substitution Augmentation Modification Redefinition Model (SAMR Model) by Puentedura (2012) (see Figure 1) could be referred in the application of technology in education. SAMR Model offers a method of seeing how technology might impact teaching and learning. It also shows a progression that adopters of educational technology often follow as they progress through teaching and learning with technology. 


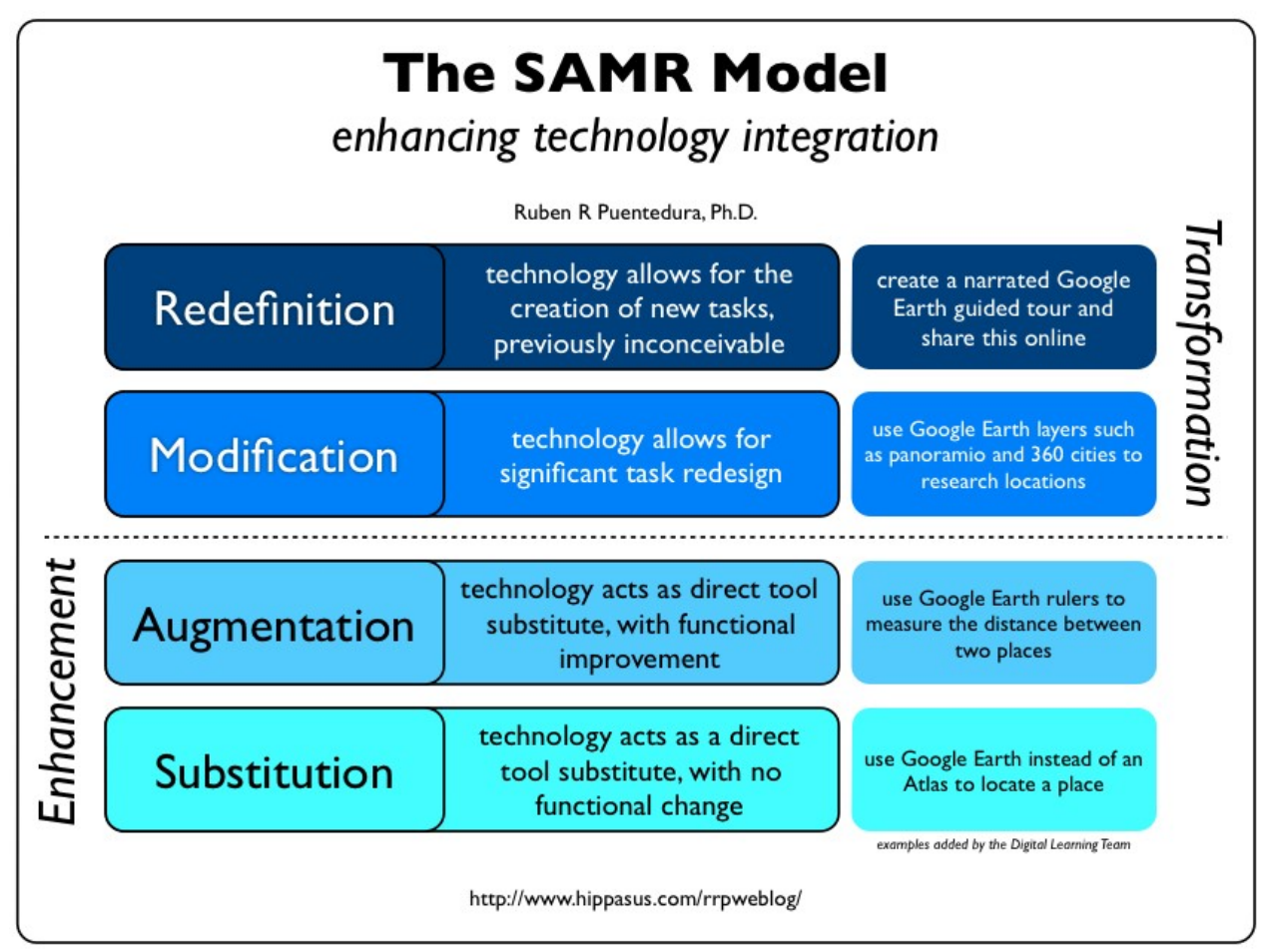

Figure 1. SAMR Model (Puentedura, 2012)

The SAMR model (Figure 1) is a useful tool for helping teachers think about their own tech use as they begin to make small shifts in the design and implementation of technology driven learning experiences to achieve the next level. Based on SAMR model, the key to successful technology integration is the efficient use of digital tools that are appropriate for the task. Technology provides us all with the ability to develop our own teaching and learning resources for use when needed.

In the application of technology in the digital era education, it is important that the teaching and learning provide ongoing and frequent feedback on performance, create a collaborative learning environment, incorporate experiential learning opportunities, create a learning environment that encourages an open exchange of ideas and create a social atmosphere though the use of peer to peer, team, and group assignments. To meet the needs of the new generation, teachers must consider learners' capabilities, preferences, experiences, frame of reference and familiarity with technology. Most importantly, the implications suggest that there is a need to rethink and redesign education that suits the need of the new generation of learners in the digital era.

\section{Conclusion}

The classroom challenge is that learners are now digital and the fact that they are beyond technology savvy while many teachers are digital immigrants. Teachers must be prepared to teach the "content of the future" using software, hardware, digital, technological, and social media. Integration of continuous grading, instant feedback, clear goals, rewards, challenges, and positive reinforcement are the new nature of education in the digital era. Above all, action is needed to promote technology in the classroom and to take advantage of increased use of social media, open educational resources, and the rise of data-driven learning and assessment. Consequently, this requires a new set of competences for teachers. It is time that the teachers, administrators, educational policy-makers and ministry of education to revisit the current education and redesign it as to meet the challenges of the digital era.

\section{References}

Balfour SP. (2013). Assessing writing in MOOCs: Automated essay scoring and calibrated peer review (tm), Research \& Practice in Assessment, Jul 1;8. 
Best, L. A., Buhay, D. N., McGuire, K., Gurholt, S., \& Foley, S. (2013). The Use of Web 2.0 Technologies in Formal and Informal Learning Settings. The Social Classroom: Integrating Social Network Use in Education. Hershey. PA: IGI Global

Hawkinson, E., Mehran, P., \& Alizadeh, M. (2017). Using MAVR to Bring New Dimensions to the Classroom. Language Teacher, 41, 31.

Howe, N. and Strauss, W. (2000). Millennials Rising: The Next Great Generation. New York: Vintage Books

Howe, N., \& Strauss, W. (2003). Millennials go to college. Washington, DC: American Association of Collegiate Registrars and Admissions Officers.

Iaremenko, N. V. (2017). Enhancing English language learners' motivation through online games.

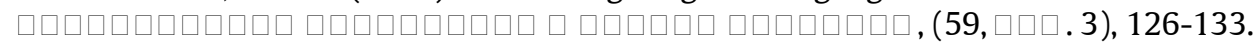

Kiran Yadaz. 2014. Role of Cloud Computing in Education. International Journal of Innovative Research in Computer and Communication Engineering. Vol. 2, Issue 2.

Kukulska-Hulme, A., Sharples, M., Milrad, M., Arnedillo-Sánchez, I., \& Vavoula, G. (2009). Innovation in mobile learning: A European perspective. International Journal of Mobile and Blended Learning (IJMBL), 1(1), 13-35.

Madini, A. A., \& Alshaikhi, D. (2017). Virtual reality for teaching ESP vocabulary: A myth or a possibility. International Journal of English Language Education, 5(2), 111-126.

Oblinger, D., Oblinger, J. L., \& Lippincott, J. K. (2005). Educating the net generation. Boulder, Colo.: EDUCAUSE, c2005. 1 v.(various pagings): illustrations..

Ozdamli, F., \& Hursen, C. (2017). An Emerging Technology: Augmented Reality to Promote Learning. International Journal of Emerging Technologies in Learning (iJET), 12(11), 21-137.

Puentedura, R. R. (2012). The SAMR model: Background and exemplars. Retrieved August, 2016.

Rothman, D. (2014). A Tsunami of learners called Generation Z. Maryl. Public Saf Online J., 1(1).

Sharples, M., Lonsdale, P., Meek, J., Rudman, P., \& Vavoula, G. N. (2007). An evaluation of MyArtSpace: A mobile learning service for school museum trips.

Skiba, D., Barton, A., (May 31, 2006). "Adapting Your Teaching to Accommodate the Net Generation of Learners". OJIN: The Online Journal of Issues in Nursing. Vol. 11 No. 2, Manuscript 4.

Yaseen, B., \& Shakir, H. (2015). Movies effects on EFL learners at Iraqi school in Kuala Lumpur. International Journal of Education and Literacy Studies, 3(3), 31-36. https://doi.org/10.7575/aiac.ijels.v.3n.3p.31 